University of Massachusetts Amherst

ScholarWorks@UMass Amherst

June 2008

\title{
Connecting 24/5 to Millennials: Providing Academic Support Services From a Learning Commons
}

Anne C. Moore

University of Massachusetts - Amherst, annem@library.umass.edu

Kimberly Wells

University of Massachusetts - Amherst, kawells@library.umass.edu

Follow this and additional works at: https://scholarworks.umass.edu/librarian_pubs

Part of the Library and Information Science Commons

\section{Recommended Citation}

Moore, Anne C. and Wells, Kimberly, "Connecting 24/5 to Millennials: Providing Academic Support Services From a Learning Commons" (2008). American Library Association Annual Conference. 40. Retrieved from https://scholarworks.umass.edu/librarian_pubs/40

This is brought to you for free and open access by the University Libraries at ScholarWorks@UMass Amherst. It has been accepted for inclusion in University Libraries Publication Series by an authorized administrator of ScholarWorks@UMass Amherst. For more information, please contact scholarworks@library.umass.edu. 


\section{UMassAmherst}

\section{CONNECTING 24/5 TO MILLENNIALS: PROVIDING ACADEMIC SUPPORT SERVICES FROM A LEARNING COMMONS}

Anne C. Moore, Associate Director for User Services, annem@library.umass.edu

Kimberly Wells, Electronic Reserves Assistant, kawells@library.umass.edu

W.E.B. Du Bois Library, University of Massachusetts Amherst 154 Hicks Way, Amherst, MA 01003-9275

ALA Annual 2008, Anaheim, Saturday, June 28, 2008, Poster Session: http://www.library.umass.edu/assessment/LCSurveyALAPS08.pdf 


\section{UMassAmherst}

\section{Introduction}

Research is scarce that investigates students' attitudes towards roving by librarians, student assistants, and technology professionals. The Learning Commons, which brings most academic support services into the Library with the intention of supporting student success, student retention, and inclusion, provides new opportunities for libraries to connect users with information and support at their convenience. What services and support do they want and use? 


\section{UMassAmherst}

\section{Introduction}

- Today's undergraduates, mostly Millennials, expect everything, including technology and research support, online, 24/7, at their convenience, and initially without intermediaries

- How do students working collaboratively in a Learning Commons want to receive technology and research support?

What services in this support-intensive environment do they use?

- What enhancements do they want?

- A library-entrant questionnaire gathered self-report input on these questions... 


\section{UMassAmherst}

\section{Problem Statement}

Research into the reasons for the instant success of establishing a Learning Commons in a large academic library is just beginning. This study investigates user preferences for reference and technical support, services, and facilities featured in the UMass Amherst W.E.B. Du Bois Library and Learning Commons through a 23-item printed questionnaire distributed to all building entrants during one 24-hour period on March 14, 2006. Results revealed the demographics of users, strong preference for face-to-face assistance (including roving). Libraries need to understand who visits a Learning Commons, how often they visit, what services they use, how they want to receive reference and technology assistance, and what enhancements they want to services and facilities. 


\section{UMassAmherst}

\section{Research Questions}

1. What are the demographics of people using the W.E.B. Du Bois Library and LC?

2. How often do users visit the Library and LC?

3. Where do users go in the building?

4. How do users want to receive research assistance and technology support?

5. What is the attitude of users toward student assistants, information technology staff, library staff and/or librarians approaching them and offering assistance while they are in the Library and/or LC?

6. What activities do users say they perform in the library building and what services currently offered do they say they use?

7. What improvements or additions do users think should be made to existing services, facilities, and technologies? 


\section{UMassAmherst}

\section{Definition of a Learning Commons}

"This new space brings together library, technology, and other campus services in an environment that fosters collaborative work, and social interaction."

http://www.umass.edu/learningcommons/ 


\section{UMassAmherst}

\section{Learning Commons' Mission Statement}

As the heart of UMass Amherst, the Learning Commons (LC) provides a welcoming, flexible, and student-focused environment. Rich in services and technologies, the LC fosters community, innovation, and the creation of new knowledge. With long hours, peer support, and a relaxed and inclusive atmosphere, the LC encourages students to make the most of their educational experience. Campus service providers pool their expertise to provide convenient access to the core academic support services that enable students to succeed and excel at UMass Amherst. The LC strives to assist students to become self-directed learners and engaged adults to build a better future. 


\section{UMassAmherst}

\section{In a Nutshell...}

- 20,000 undergraduates; 5,000 graduate; 1,200 faculty

$\Rightarrow 90 \%$ owned laptops in 2007; 82\% in 2006; 70\% in 2005

3.2 million volumes; 55 librarians; 75 staff; $\$ 12$ million annual budget

$\rightarrow 26$ Floor W.E.B. Du Bois Library

$\Rightarrow$ For \$2.5 million, renovated Lower Level in 4 months; opened Sept. 2005; \$600k annual operating budget

- 30,000+ square feet; 400 seats; 17 glass study rooms

- Hours (24/5): Sunday 11 a.m. - Friday 9 p.m.; Saturday 9 a.m. -9 p.m.

- Gate count: 4,500-7,500 per day; 1 million annually

- Users are: 85\% undergraduate; 50/50 gender; all majors; diverse; $35 \%$ daily users 


\section{UMassAmherst}

Gate Counts in the W.E.B. Du Bois Library - October

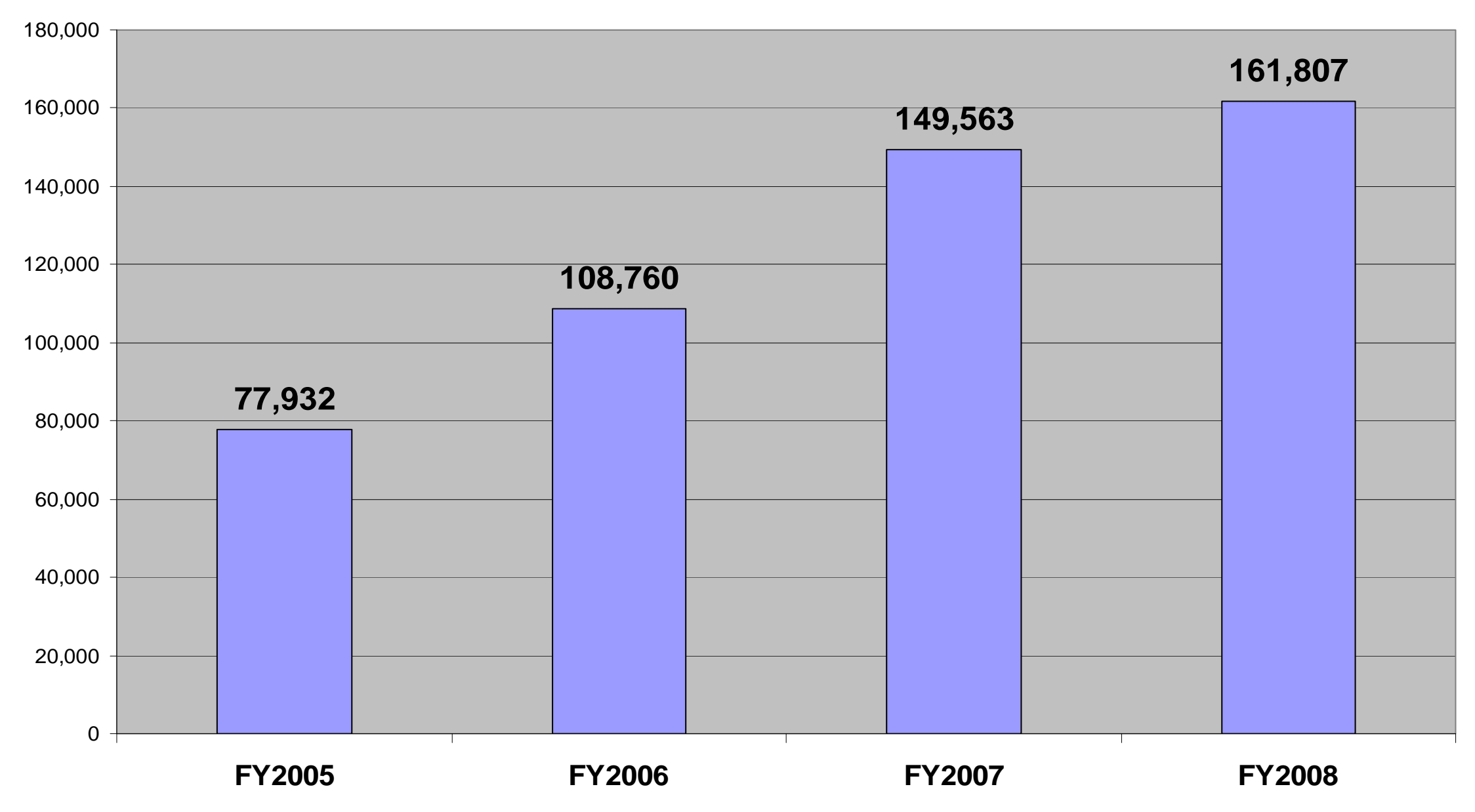




\section{UMassAmherst}

\section{What Can Students Do In The LC?}

- Collaborate

$\rightarrow$ Socialize

Eat and drink

Meet in group study rooms and spaces

- Study

$\Rightarrow$ Use library collections

$\Rightarrow$ Use licensed software and databases

- View exhibits

$\Rightarrow$ Attend events and training

- Attend library instruction

- Copy, print, scan
- Ask any kind of question

- Get technology, writing, research, information, career services, academic advising, international programs, adaptive technology, academic tutoring, supplemental instruction, and all library services

$\Rightarrow$ Use wireless

- Borrow tablet PC/laptops, projectors, and headphones

$\Rightarrow$ Buy office supplies 


\section{UMassAm}

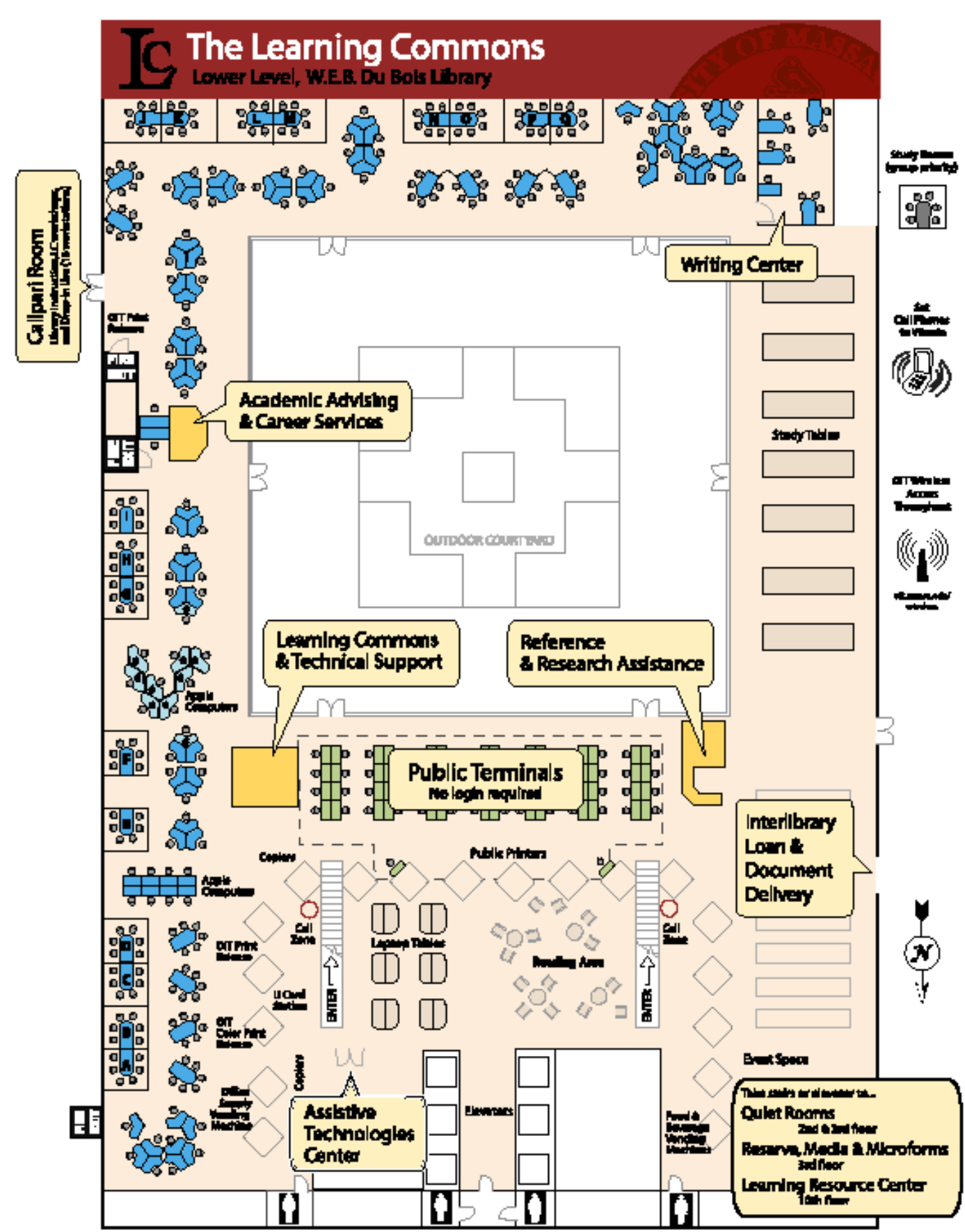




\section{UMassAmherst}

\section{Academic Support Services}

$\Rightarrow$ Library Services

W Writing Center

$\rightarrow$ Office of Information Technologies

$\rightarrow$ Academic Advising

- International Programs

$\rightarrow$ Career Services

- Learning Resource Center (tutoring; supplemental instruction)

- Assistive Technology Center

- ALANA (African, Latino, Asian/ Pacific Islander \& Native American Diversity and Opportunity Program) 


\section{The Learning Commons}

\section{W.E.B. Du Bois Library}

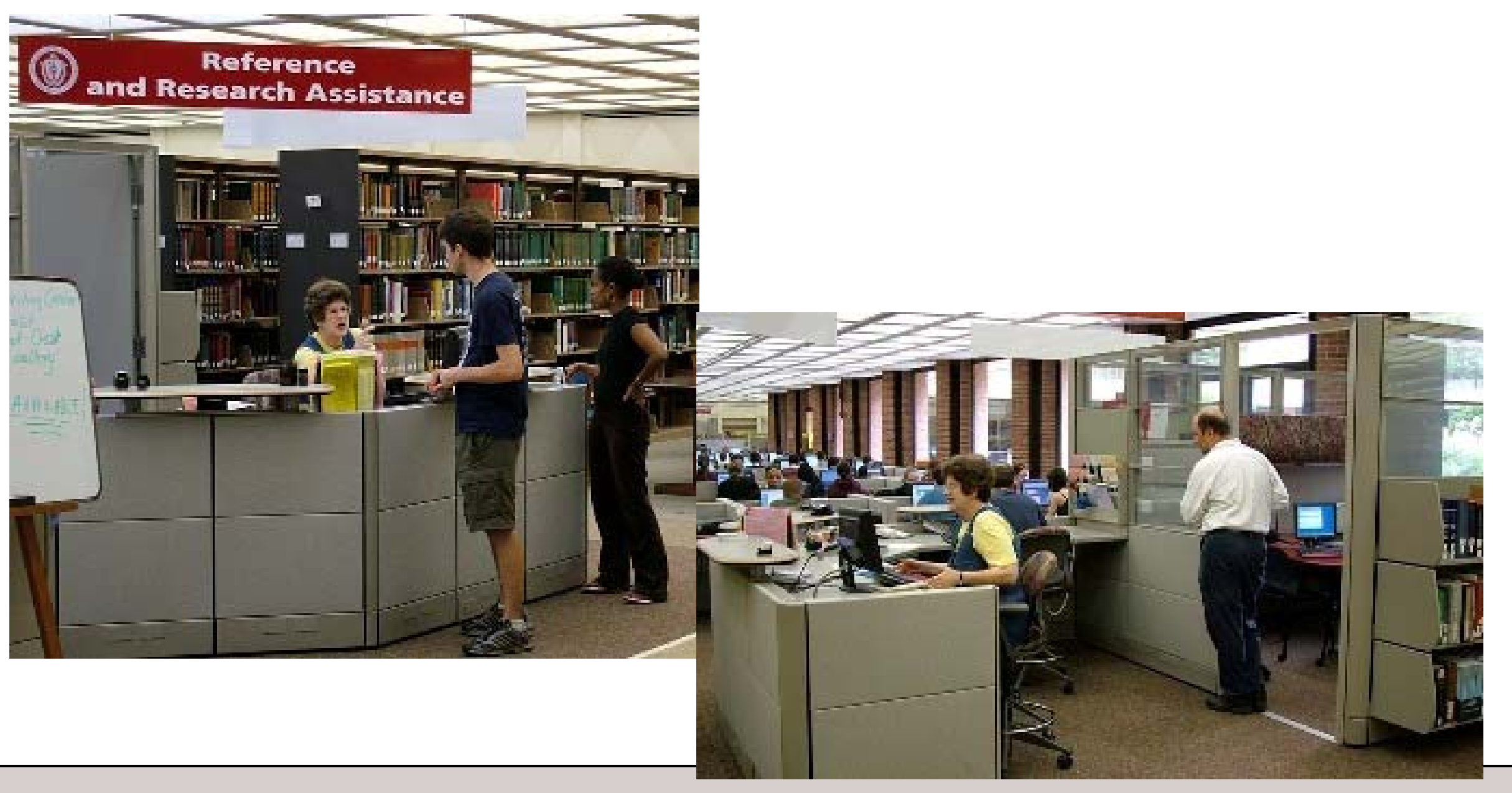




\section{The Learning Commons}

\section{W.E.B. Du Bois Library}

\section{Writing Center}
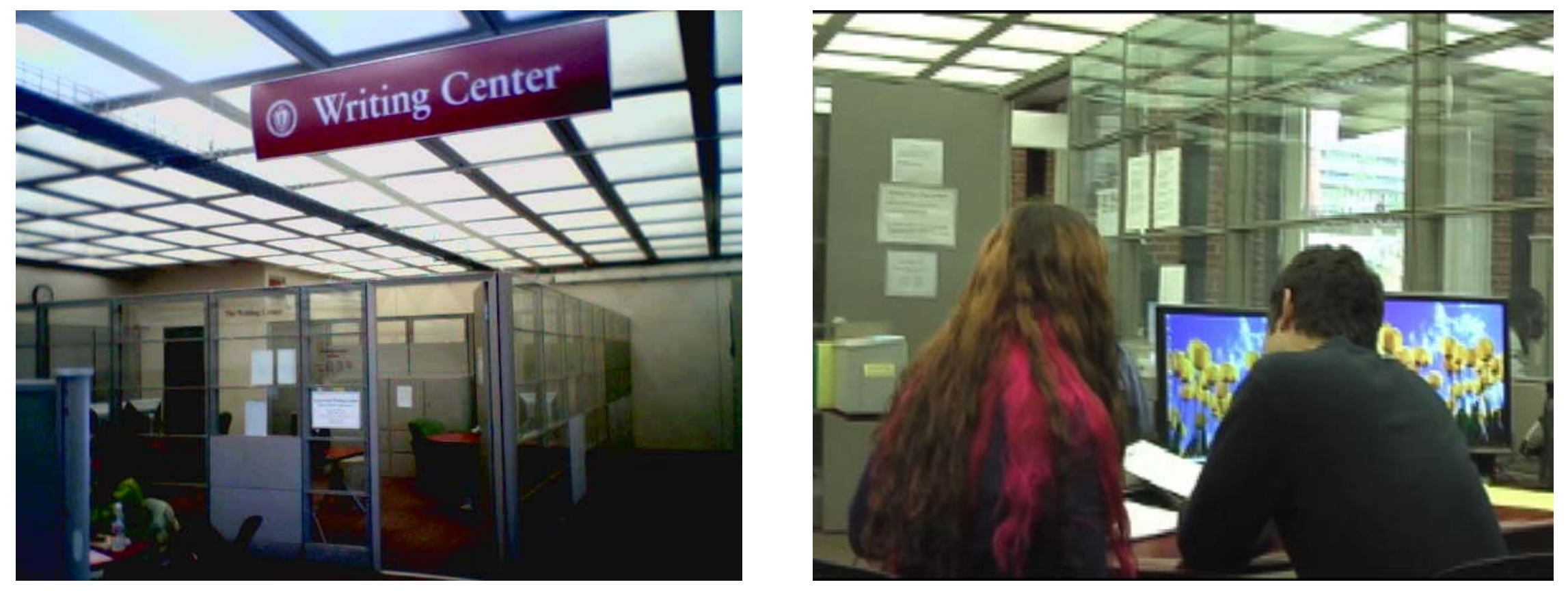


\section{UMassAmherst}

\section{Academic Advising Link \& Career Services}

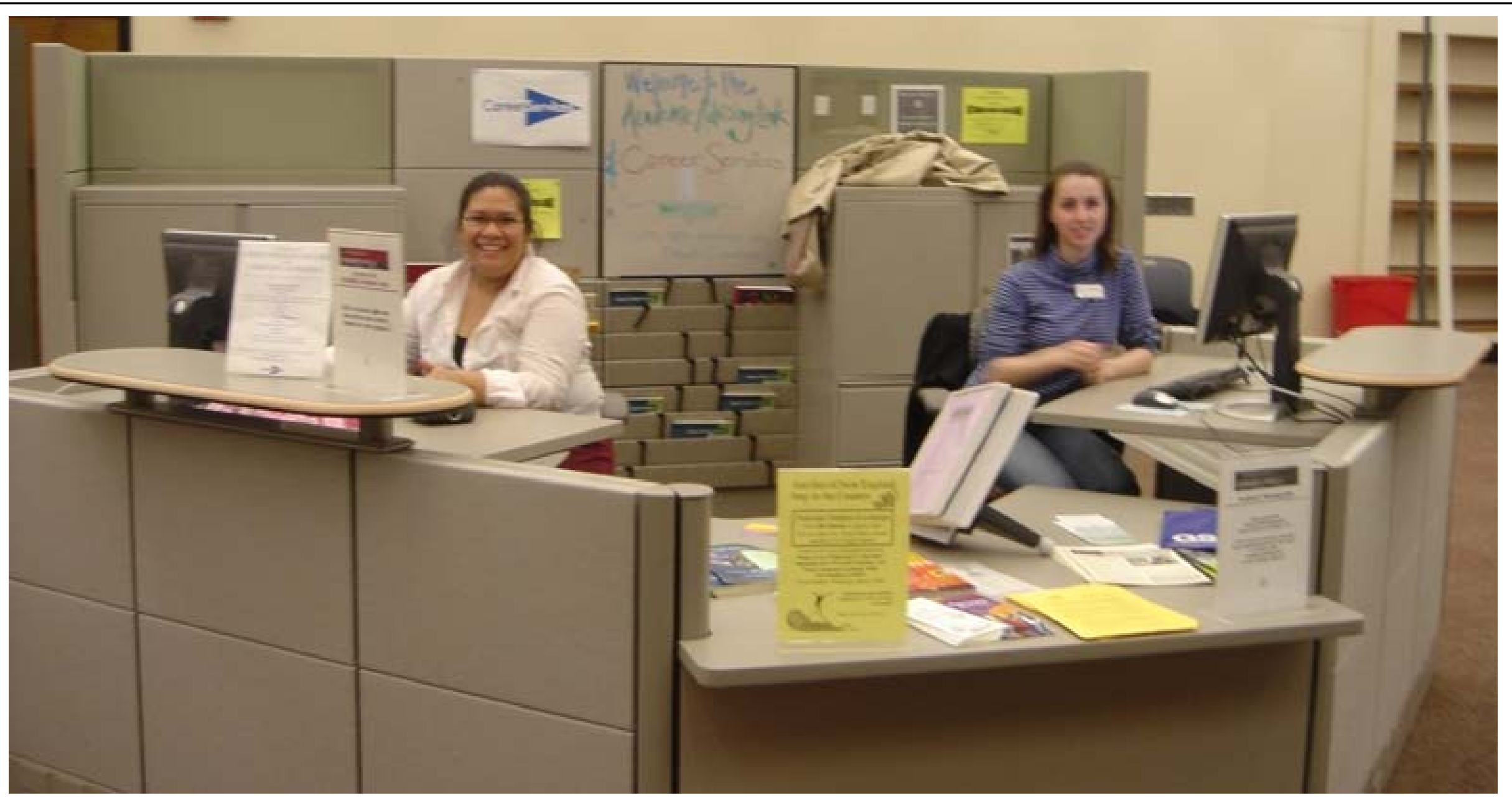




\section{The Learning Commons}

W.E.B. Du Bois Library

Quiet study area (Floors $2 \& 3$ )

\section{Comfortable seating}

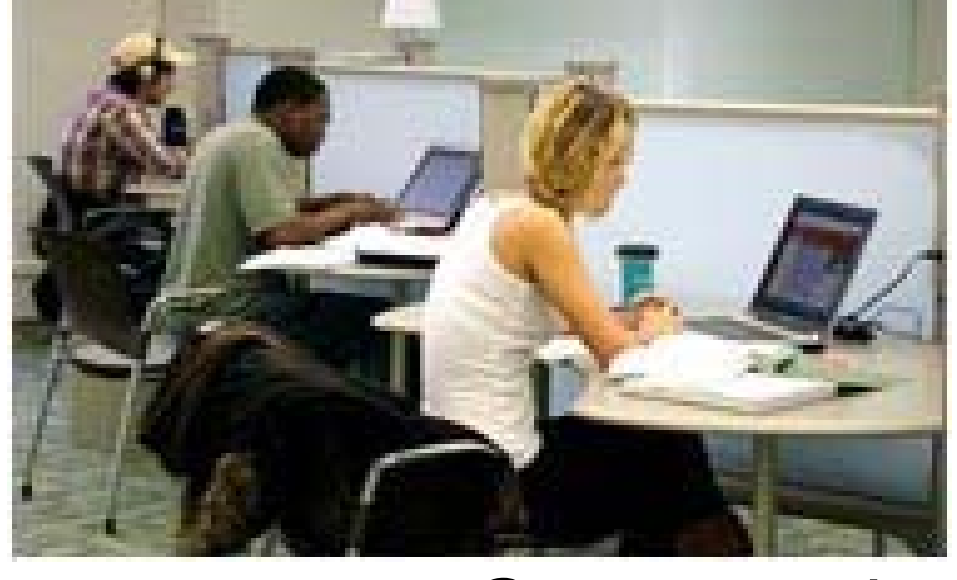

Group study rooms
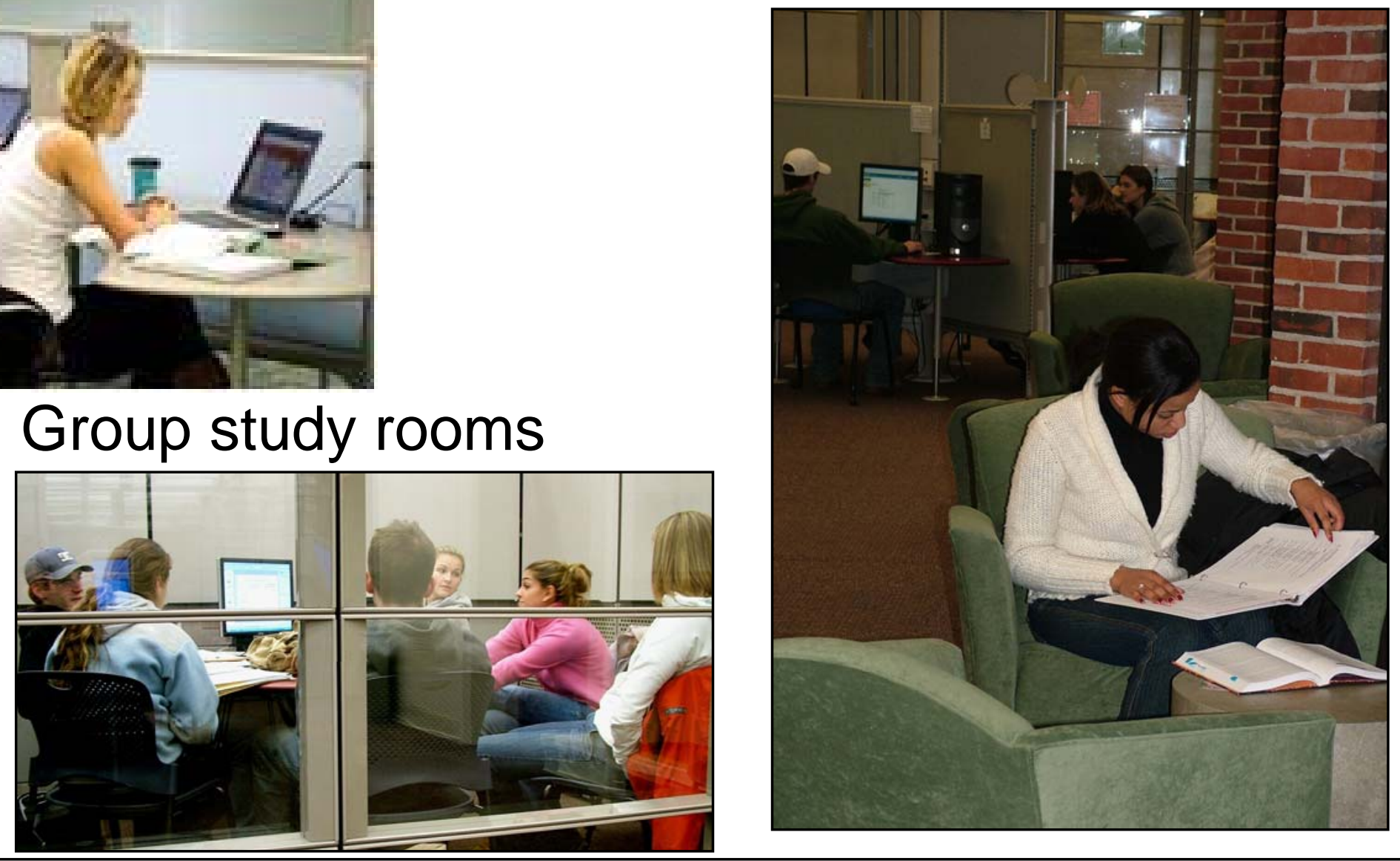


\section{The Learning Commons}

W.E.B. Du Bois Library
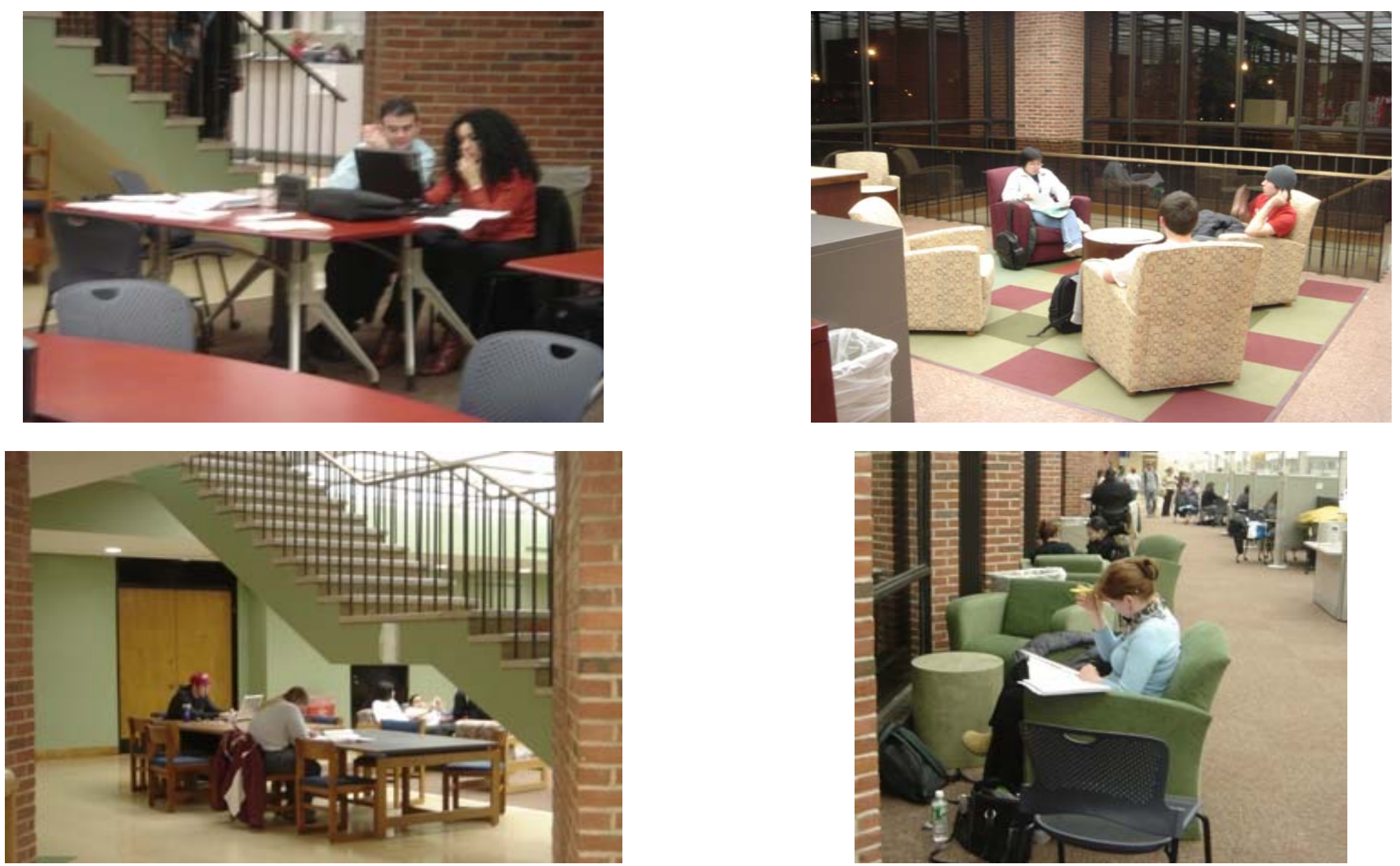


\section{The Learning Commons}

W.E.B. Du Bois Library
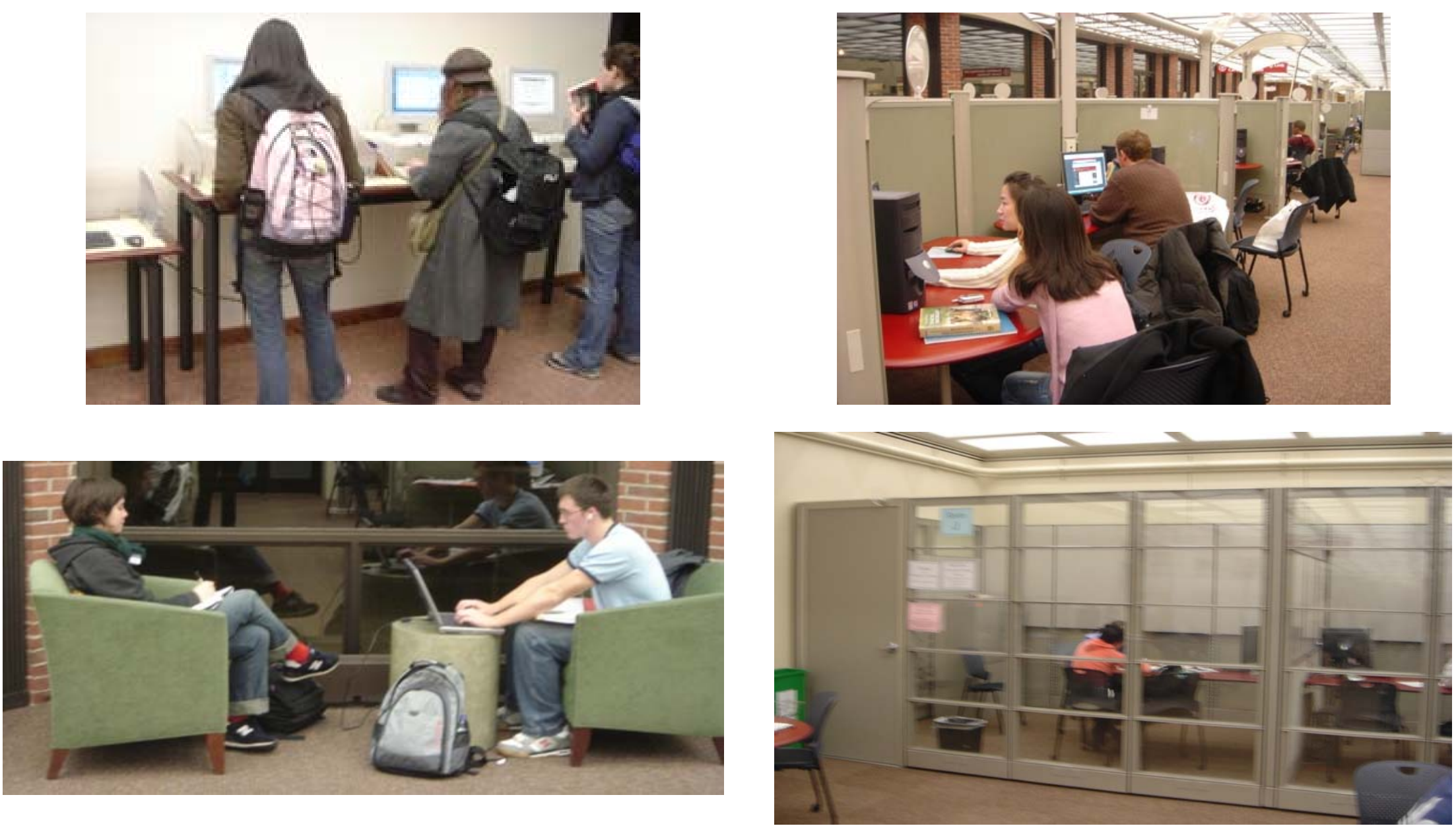


\section{UMassAmherst}

\section{Procrastination Station Café}

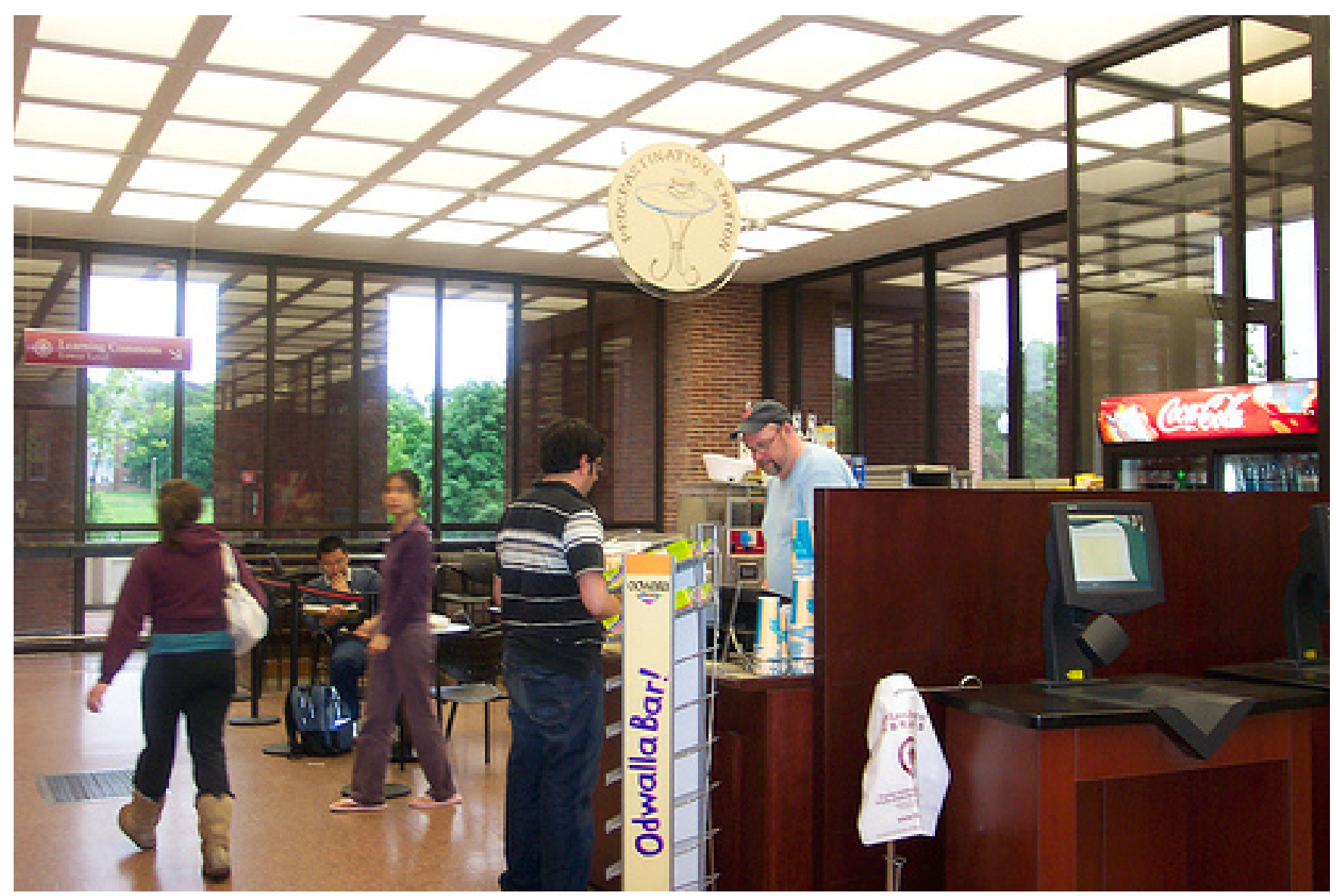




\section{UMassAmherst}

What are the Service Expectations of Millennials?

$\Rightarrow$ Online

$\Rightarrow 24 / 7$

- Self-service

$\rightarrow$ Immediate

$\Rightarrow$ Easy and intuitive

$\Rightarrow$ Technology-based

- Through their preferred communication modes: cell phone, text message, IM, email, Facebook, blog, whatever comes next...

... but they thrive on SOCIAL INTERACTION and value the advice of EXPERTS 


\section{UMassAmherst}

How can Library and IT Staff Best Help Millennials?

$\Rightarrow$ Provide reference and liaison services online and through roving

$\Rightarrow$ Integrate services

- Envision technology and reference/research support as distinct services

$\Rightarrow$ Offer one-on-one consultations

$\Rightarrow$ Offer office hours in other academic buildings and cafés

- Connect students with the right person to help them: technology or subject specialist 


\section{UMassAmherst}

\section{Methodology - Logical Structure}

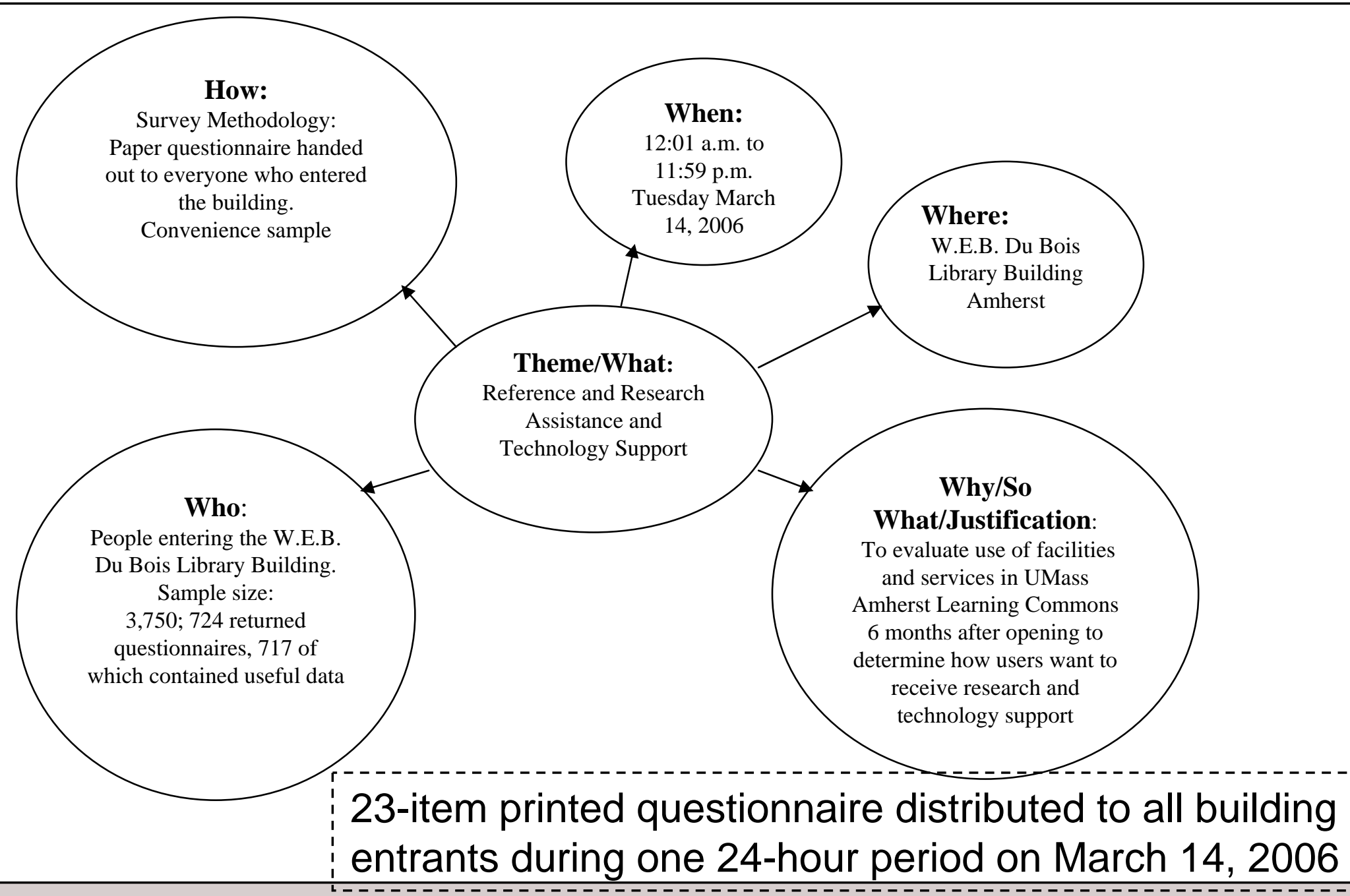




\section{UMassAmherst}

\section{Those who Entered on March 14, 2006}

- 85\% Undergraduates

-50/50 gender split

- All majors represented (Social \& Behavioral Sciences 33\%; Humanities \& Fine Arts 18\%; Natural Sciences \& Mathematics 16\%; School of Management 15\%)

-75\% visit the Lower or Learning Commons' Level

- 35\% visit daily; $94 \%$ visit at least once a week

- Traffic: Tuesday (88\%), Wednesday, Monday, Thursday, Sunday, Friday, Saturday

$\Rightarrow 60 \%$ come in the afternoon or evening; $23 \%$ overnight; $22 \%$ morning

$\Rightarrow 48 \%$ study in the Library 


\section{Occurrence of Library Visits}

$$
[\mathrm{N}=713]
$$

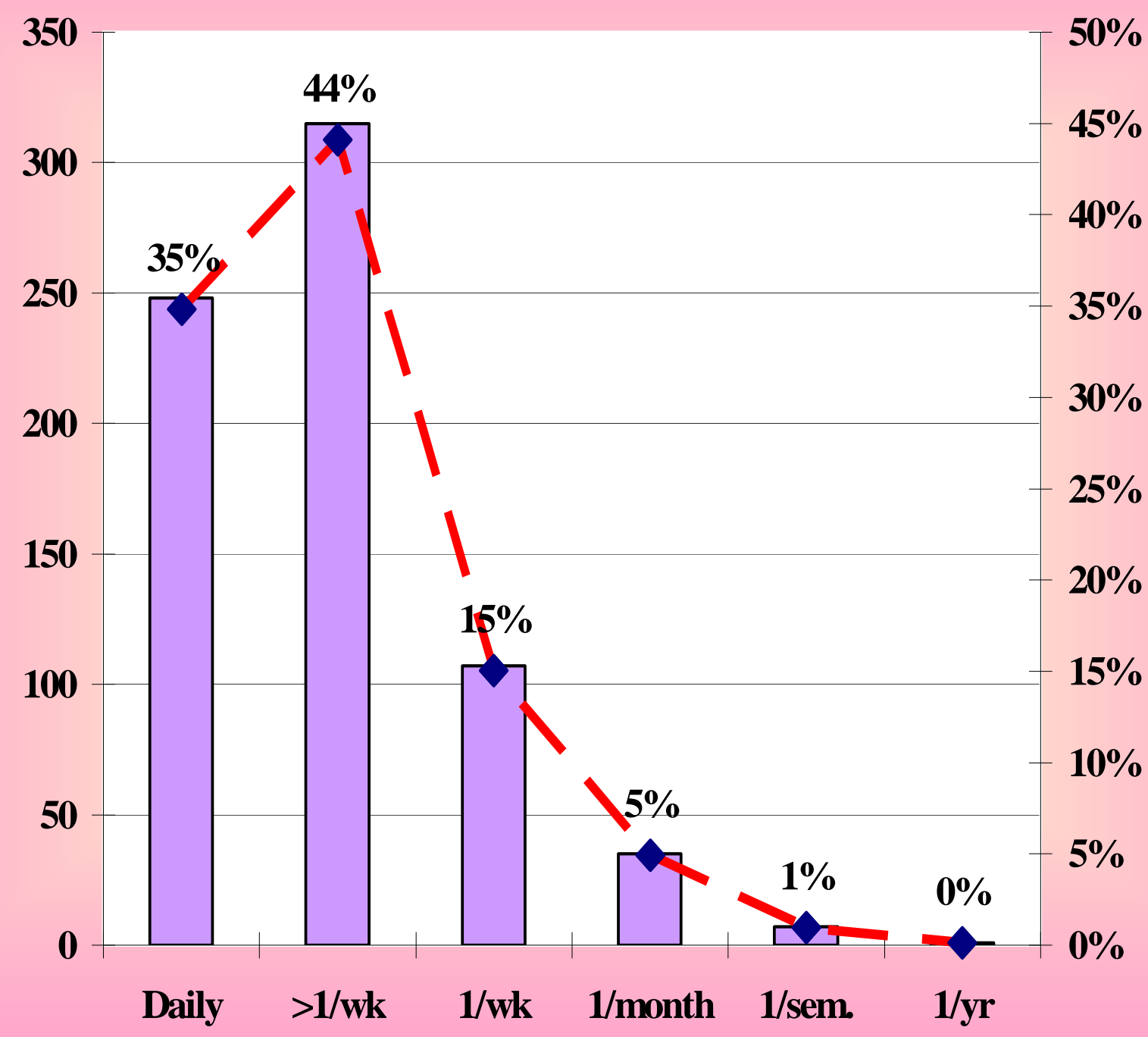

How Frequently do you visit the Library? 


\section{Ethnicities}

\section{[N = 549 Survey] \\ [ $\mathrm{N}=20,849$ UMass ]}
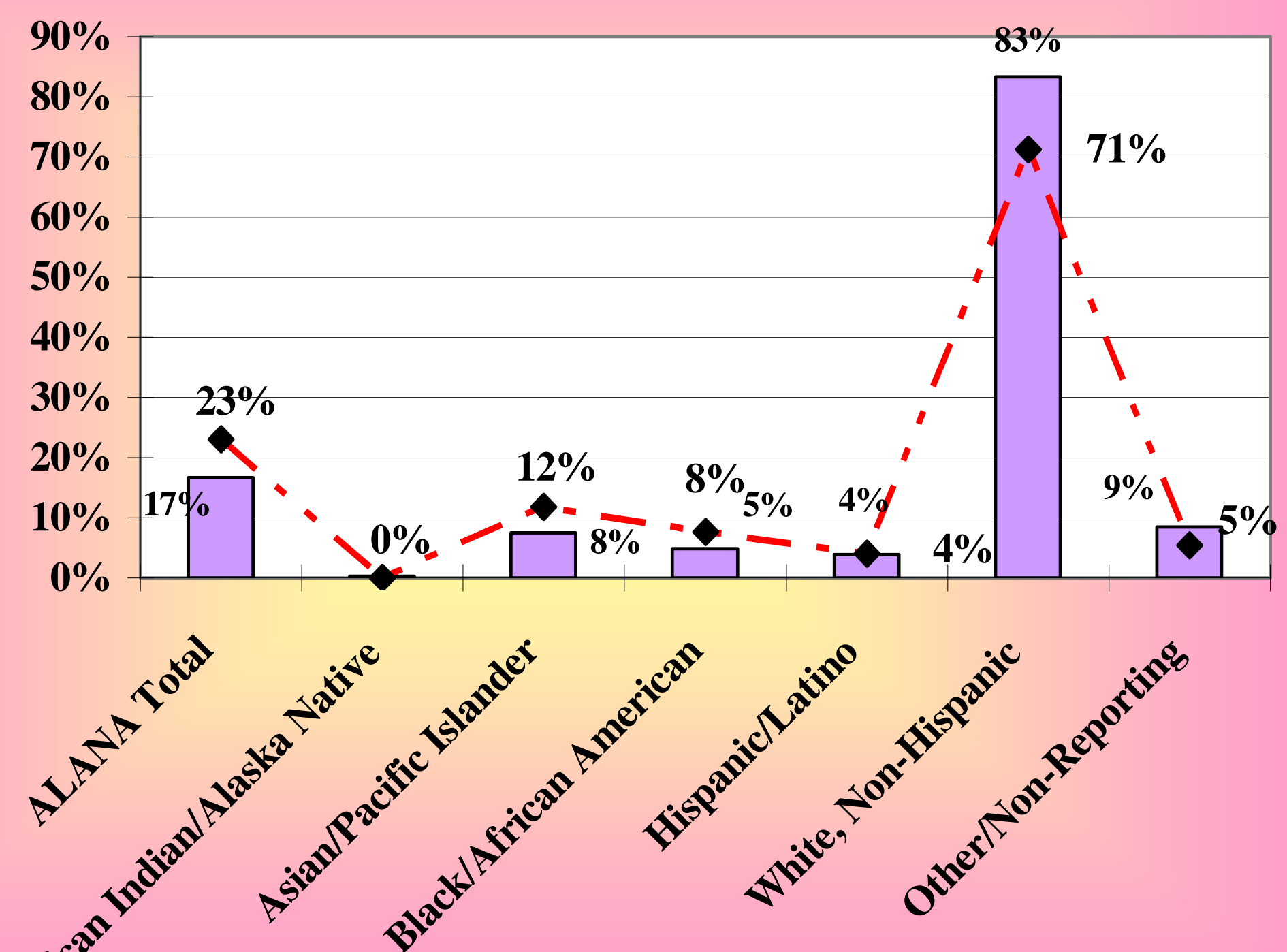


\section{UMassAmherst}

\section{Those Who Entered on March 14, 2006 (n=682)}

- More diverse group than the campus population

\begin{tabular}{|l|l|l|}
\hline Ethnicity & UMass & Survey \\
\hline Caucasian & $83 \%$ & $71 \%$ \\
\hline African-American & $5 \%$ & $8 \%$ \\
\hline Hispanic & & \\
\hline Asian & $4 \%$ & $4 \%$ \\
\hline
\end{tabular}




\section{Department Majors}
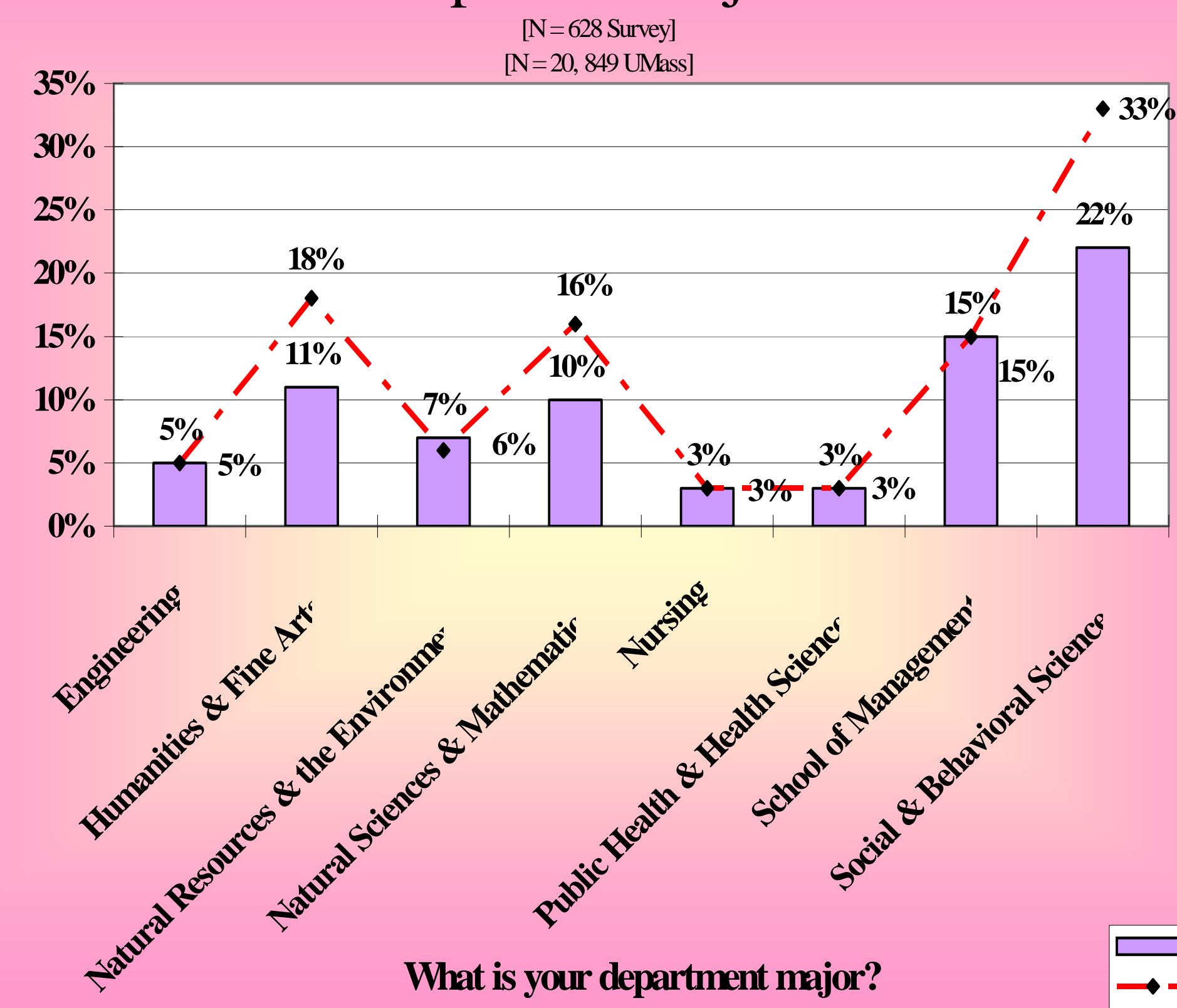


\section{UMassAmherst}

\section{What Services Are They Using? March 14, 2006}

- General Information Desk:

$\rightarrow$ Reserves:

- Computer Classrooms:

- Circulation:

$\Rightarrow$ Reference and Research Assistance:

- Learning Resource Center:

- OIT Help Desk:

$\Rightarrow$ ILL:

- Special Collections:

- Writing Center:

$\rightarrow$ Academic Advising:
$75 \%$

$72 \%$

$65 \%$

$60 \%$

$41 \%$

$39 \%$

$38 \%$

$34 \%$

$19 \%$

$18 \%$

$6 \%$ 


\section{Type of Technology Support Preferred}

[N=641]

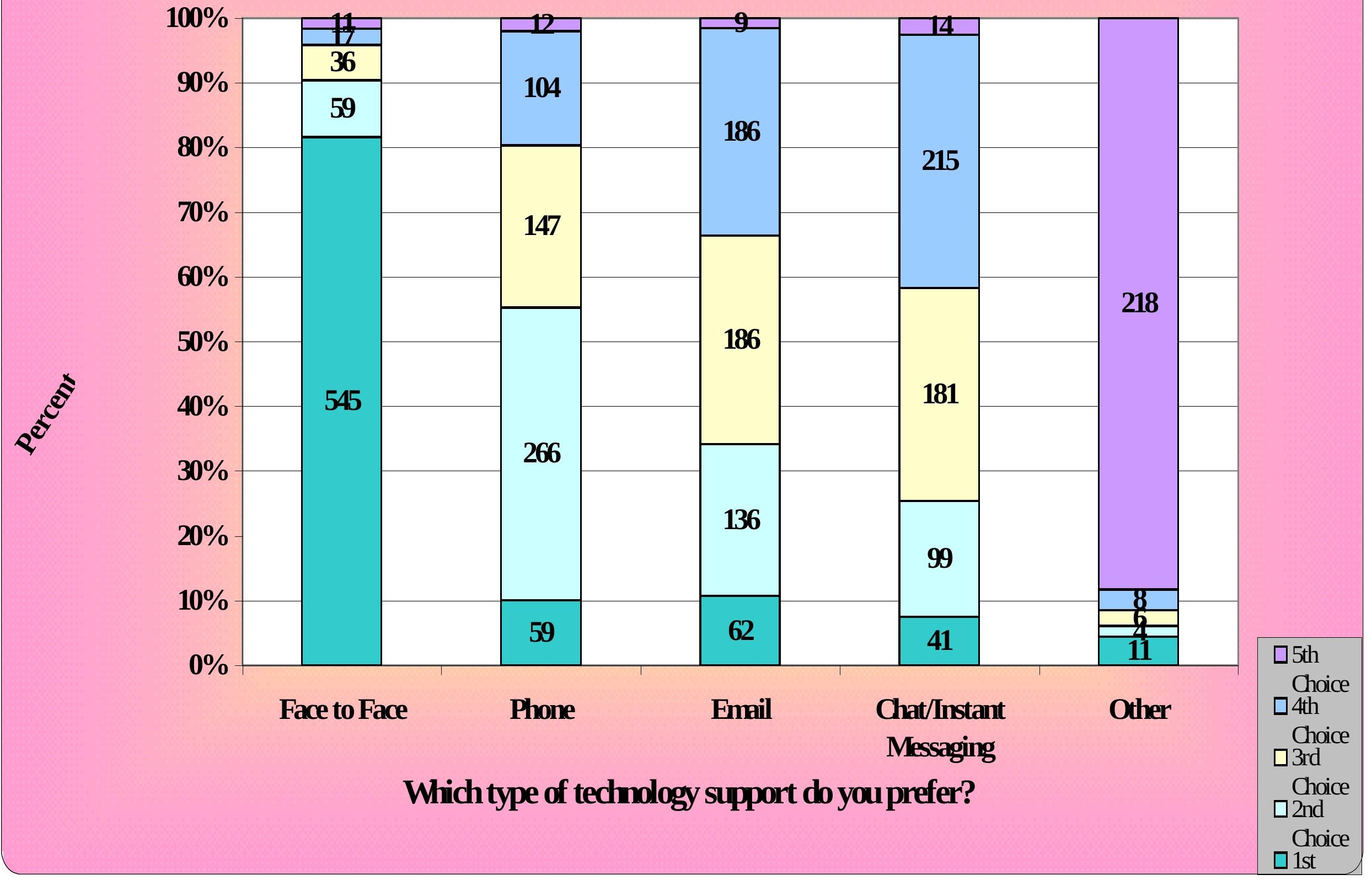




\section{Reference and Research Interaction}

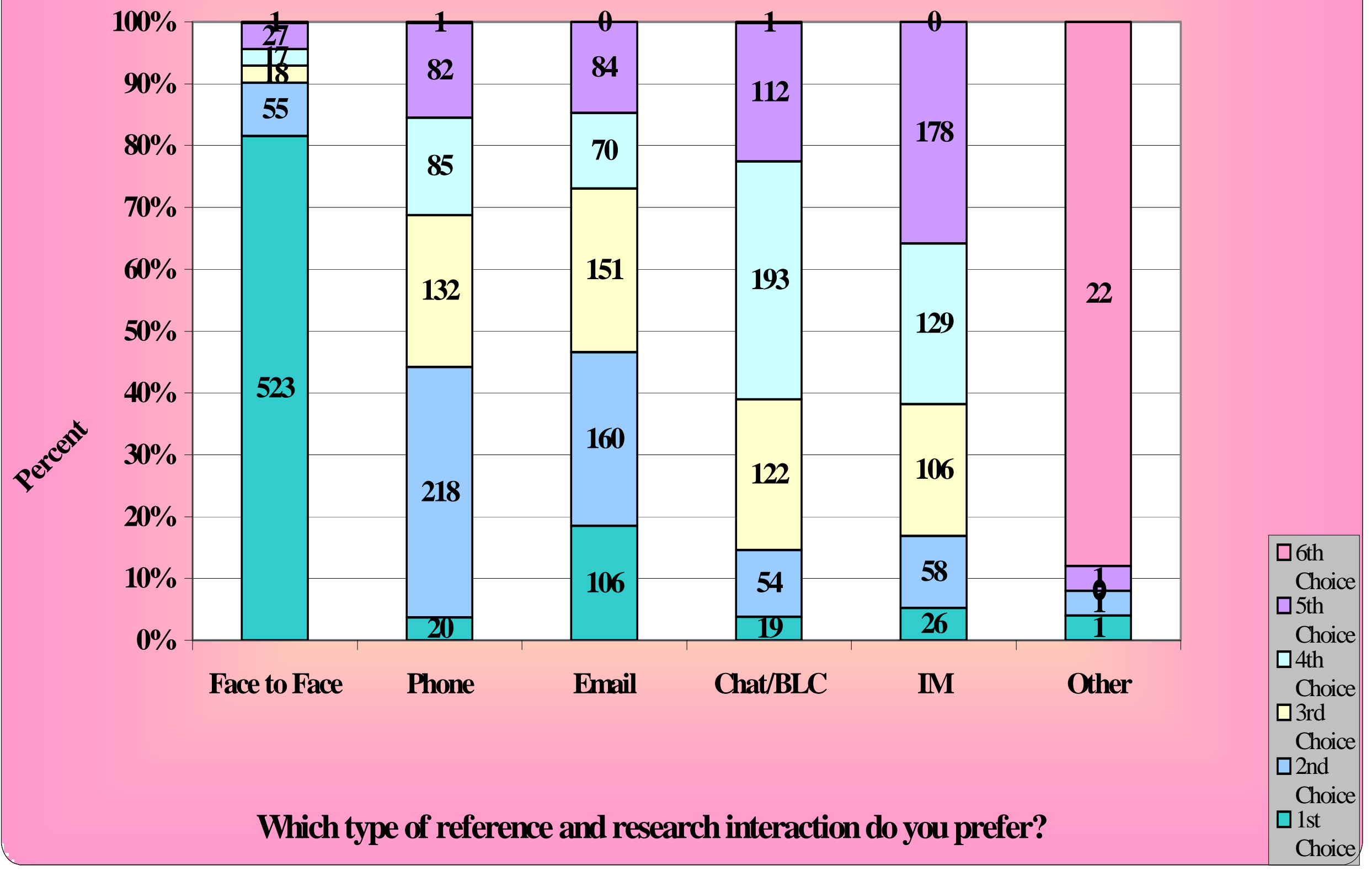




\section{Feelings About Roving}

$[\mathrm{N}=615]$

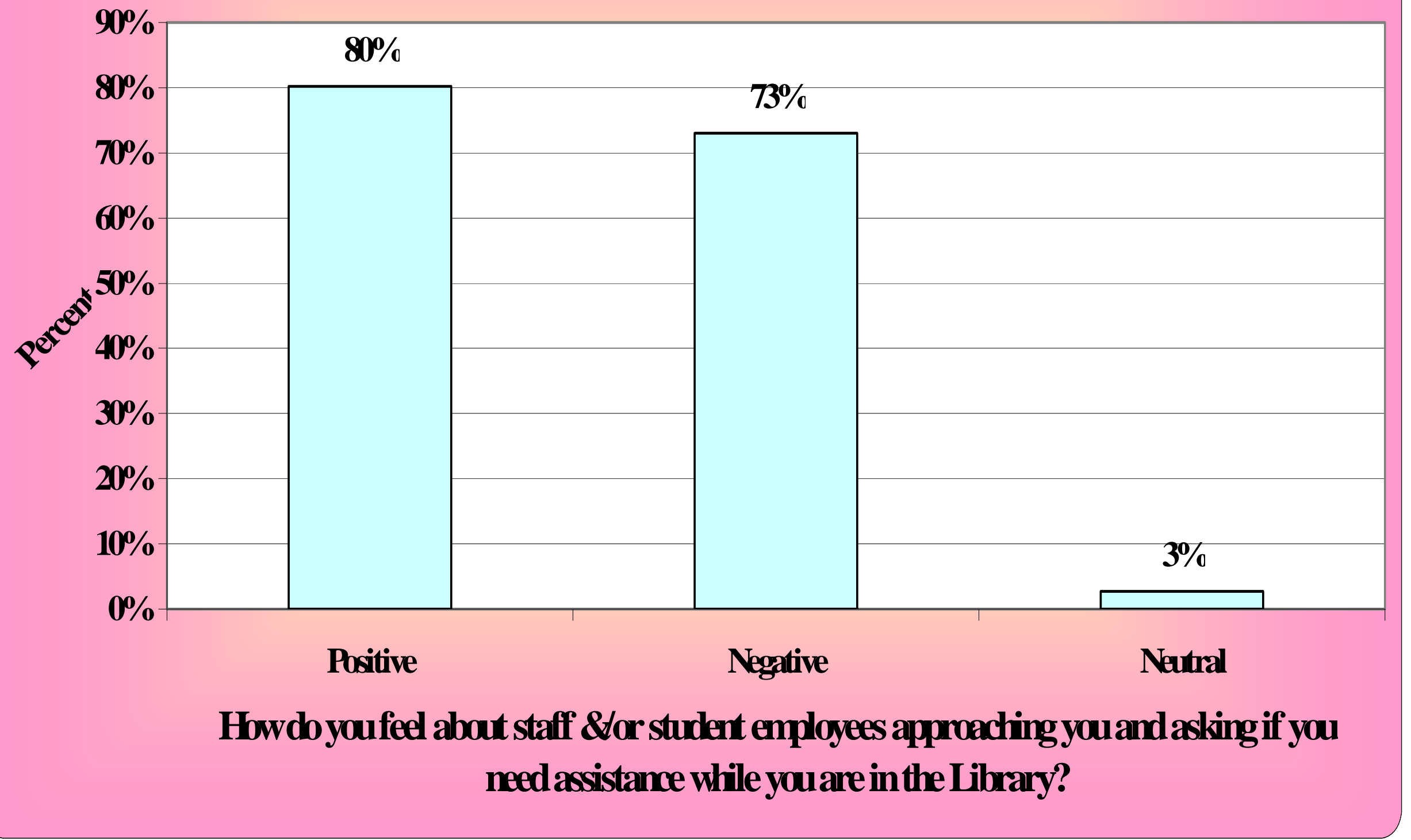




\section{Roving Learning Commons}

$[\mathrm{N}=656]$

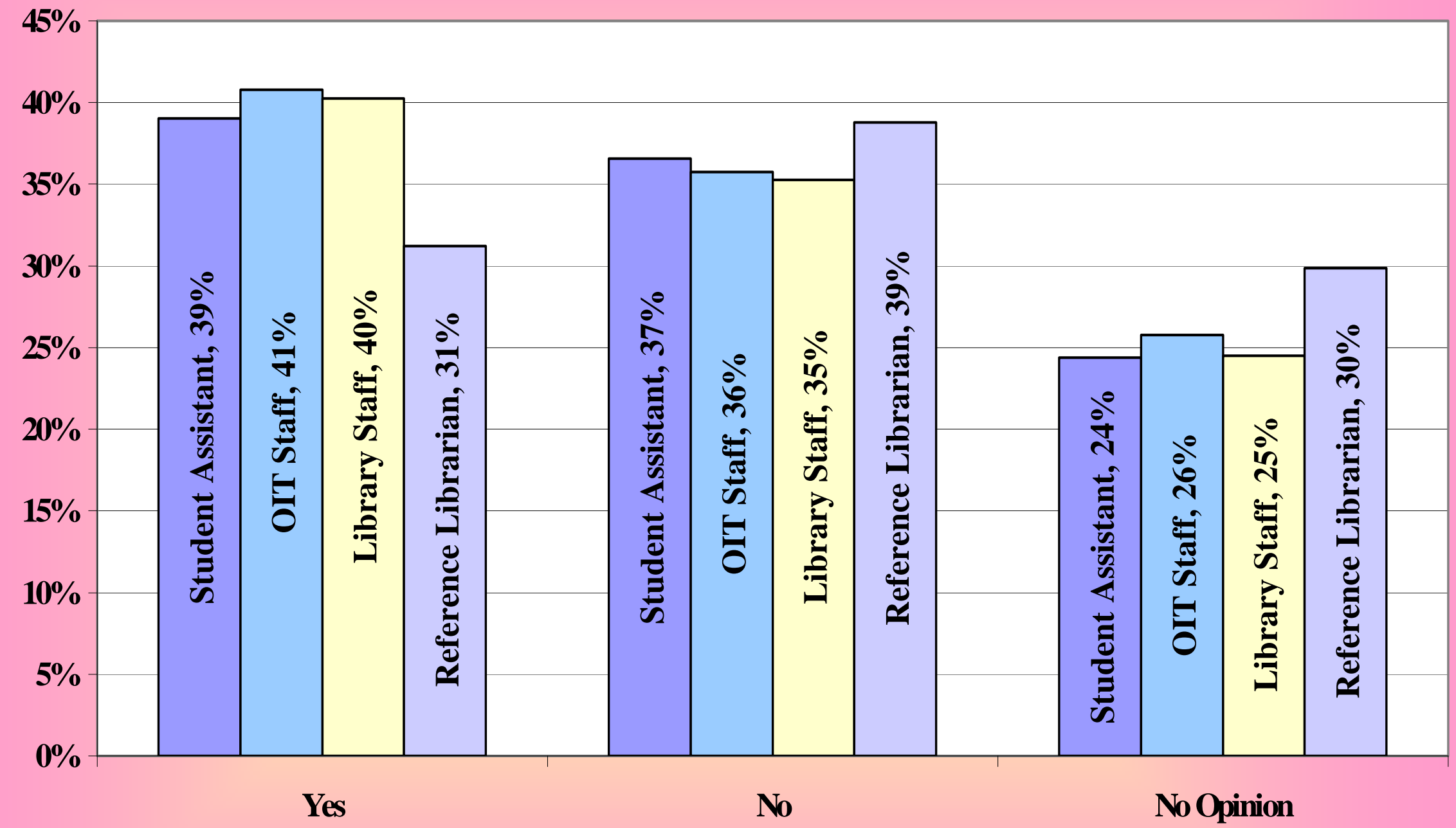

Do you wish that staff would circulate periodically through the Learning Commons to see if you need assistance? 


\section{Roving Elsewhere}

[N=642]

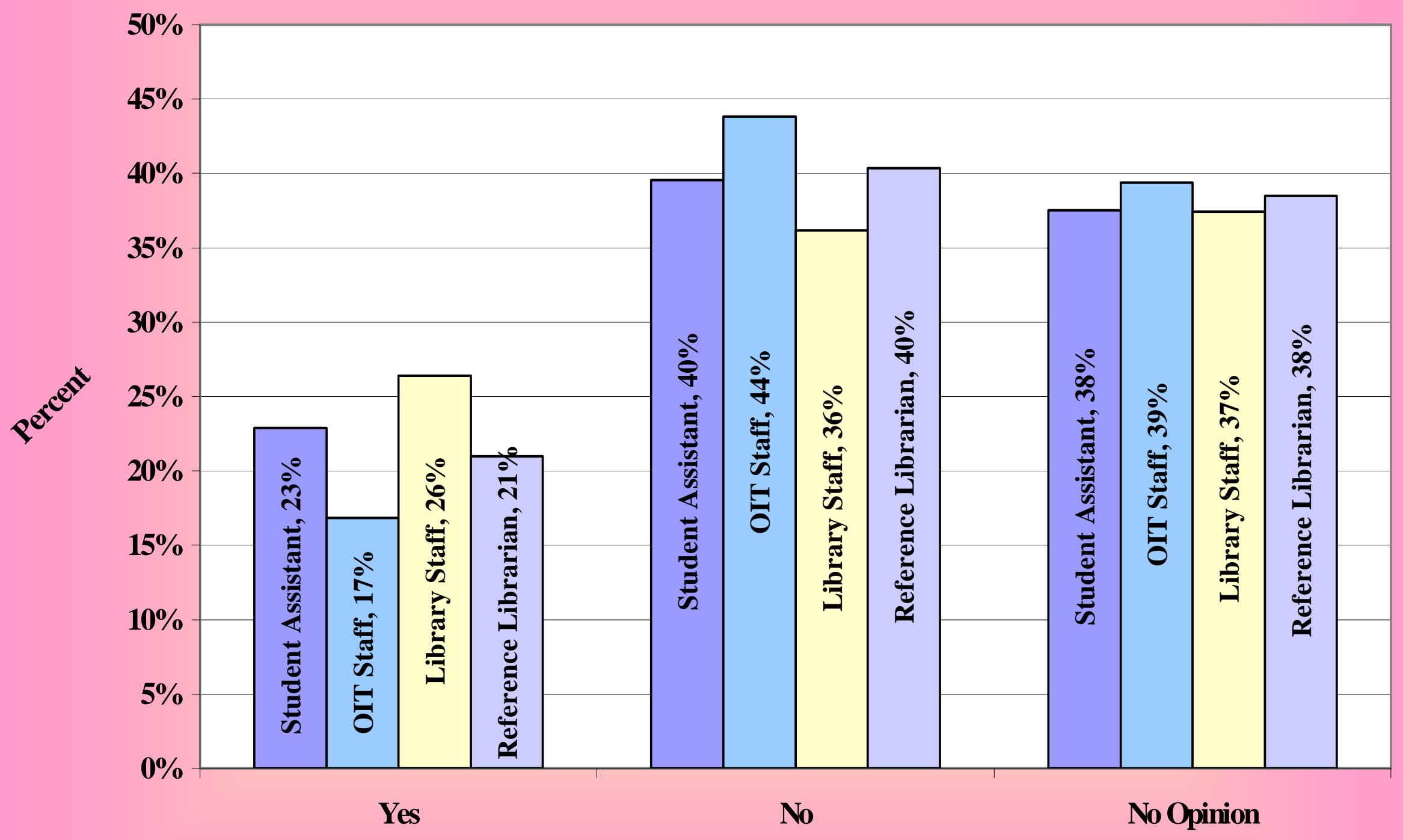

Do you wish that staff would circulate periodically elsewhere in the Library? 


\section{UMassAmherst}

\section{IT Web-based Survey Results* ${ }_{[n=499]}$}

- How often do you visit the Learning Commons?

$\Rightarrow$ More than once per week: 24\% ('07); 28\% ('06); 31\% (students of color '07); $22 \%$ (white ‘07)

- How often have you had difficulty finding an open computer workstation when you are in the Learning Commons?

- Very often: 35\% ('07); $23 \%$ ('06); $16 \%$ (1' ${ }^{\text {st }}$ yr students ‘07); 51\% (seniors '07)

- How conducive or non-conducive is the atmosphere in the Learning Commons for studying and concentrating on your academic work?

$\Rightarrow 73 \%$ conducive

- To what extent do you feel that working in the Learning Commons has improved your study habits?

- To a great or very great extent: $19 \%$ (students of color 30\%; white 16\%)

* Fall 2007 responses compared to Fall 2006 responses 


\section{UMassAmherst}

\section{What's Important To Users?}

$\Rightarrow$ Food and drink

- Computers, scanners, printers, software, Wireless, electricity

- Flexible, comfortable, and attractive furnishings they can move around

$\Rightarrow$ Responsive service; Customer-focused, committed, and knowledgeable staff

- Custodial and clean workstations and surfaces

- User behavior policies

- Security and building maintenance

- An awesome Web site and blog

- Responsive service providers and admin ... new services

$\Rightarrow$...It is their space! 


\section{UMassAmherst}

\section{Enhancements and Improvements: They Want More...}

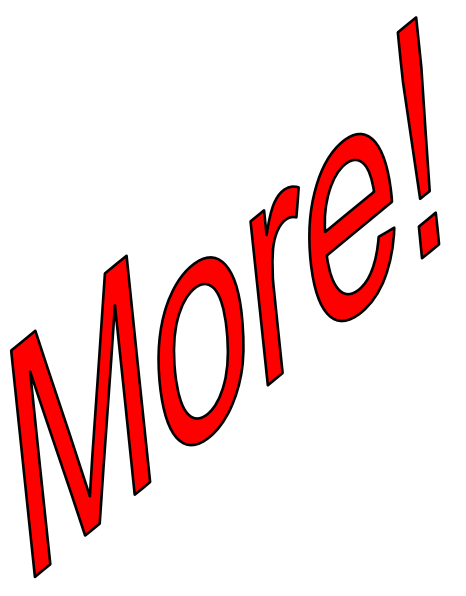

- Computers

- Learning Commons spaces on other floors

* Group Study Rooms

- Electrical outlets

* Wireless access

- Food and drink availability and choices

- Hours: $24 / 7$

- Seats

Q Quiet study areas

- Printers and Quick print stations

- Copiers 


\section{UMassAmherst}

\section{Conclusion}

Although users say they are satisfied with our current library and technology services, they have high expectations and expect Learning Commons' to constantly evolve to meet their changing needs. Librarians and technologists might want to ask themselves...

A Are we there for our users when, where, and how they need assistance? $\Rightarrow$ Are we embracing the technologies and communication media students are using?

$\Rightarrow$ Are we providing intuitive web-based access and support tools?

Are libraries and IT departments providing value-added and unique services that satisfy an immediate need?

$\Rightarrow$ Are we thinking of technology and research support as services rather than desks?

$\Rightarrow$ Are we moving out from behind our service desks to meet students where they are?

$\Rightarrow$ What improvements should be made to existing services and facilities to meet the needs of today's and tomorrow's students? 


\section{UMassAmherst}

Anne C. Moore

Associate Director for User Services

annem@library.umass.edu

Kimberly A. Wells, Electronic Reserves Assistant kawells@library.umass.edu

W.E.B. Du Bois Library

University of Massachusetts Amherst 154 Hicks Way, Amherst, MA 01003-9275 